УДК 664.8.032:634.23, DOI 10.31210/visnyk2018.04.08

(C) 2018

Василишина О. В., кандидат сільськогосподарських наук

Уманський національний університет садівництва

\title{
ВПЛИВ ОБРОБКИ РОЗЧИНОМ САЛІЦИЛОВОЇ КИСЛОТИ НА ЯКІСТЬ ПЛОДІВ ВИШНІ ПІСЛЯ ЗБЕРІГАННЯ
}

\section{Рецензент - кандидат сільськогосподарських наук К. В. Костецька}

Плоди вишні мають короткий термін зберігання, всього лише 15 діб при температурі $0^{\circ} \mathrm{C}$. Продовжити його можна шляхом застосування відповідних заходів первинної обробки та зберігання продукиії. Один з них - обробка плодів вишні розчином саліцилової кислоти перед зберіганням. Метою нашої роботи було вивчення впливу попередньої обробки розчином саліцилової кислоти на хімічний склад плодів вишні. Для изього плоди вишні сортів Шпанка та Лотівка 2016-2017 року врожаю обприскували за день до збирання водним розчином 50 мг/л чи 100 мг/л саліщчилової кислоти. Висушували природним иляхом. Через 24 години знімали з дерева плоди, типові за забарвленням та формою, укладали в ящики №5 по 5 кг у кожний згідно з методичними вказівками щуодо зберігання плодів, овочів та винограду. Зберігали в умовах холодильних камер кафедри технології зберігання $і$ переробки плодів та овочів за температури $5 \pm 0,5^{\circ} \mathrm{C}$ та

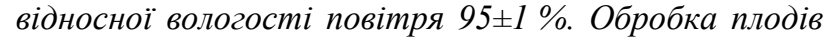
вишні розчином саліцилової кислоти дала змогу подовжити термін зберігання до 21 доби. Найефективнішою виявилась обробка 100 мг/л розчином саліцилової кислоти. Природні втрати маси при иььому становлять 4,9-5,1\%, втрати у вмісті сухих розчинних речовин - 5,3-6,6\%, кислот - 12,3-9\%. Вміст аскорбінової кислоти знижується в 1,3-1,1 рази.

Ключові слова: плоди вишні, зберігання, саліцчилова кислота, сухі розчинні речовини, аскорбінова кислота.

Постановка проблеми. Вишня - неклімактеричний плід 3 коротким терміном зберігання, всього лише 15 діб при температурі $0{ }^{\circ} \mathrm{C}$. Щорічно близько $20 \%$ втрат продукції маємо через відсутність відповідних заходів первинної обробки та зберігання продукції. Основна частина втрат виникає через фізіологічні розлади протягом зберігання. Тому на сьогодні ведеться активний пошук способів первинної обробки перед зберіганням продукції, які б запобігали розвитку хвороб.

Аналіз основних досліджень і публікацій, у яких започатковано розв'язання проблеми. Саліцилова кислота відіграє важливу роль у широкому спектрі фізіологічних та метаболічних реакцій, включаючи затримку дозрівання через затримання синтезу етилену, а також зменшення фізіологічних захворювань плодів абрикоса, черешні, персика [4, 10-12]. Також саліцилова кислота відіграє основну роль у рості і розвитку рослин. Ії дія пов'язана з захисними реакціями та забезпеченням захисту від атаки збудників фізіологічних хвороб [5, 7-9]. Обробка плодів саліциловою кислотою знизила розпад, викликаний грибом Botrytis cinerea, у томатах та сприяла затримці процесу достигання [6]. Крім того, використання саліцилової кислоти сприяло зменшенні пошкоджень слив та персика [7].

Проте вплив обробки саліциловою кислотою на плоди вишні та їх фізіолого-біохімічні показники не було досліджено.

Тому метою нашої роботи було вивчення впливу попередньої обробки розчином саліцилової кислоти на хімічний склад плодів вишні.

Матеріали і методи досліджень. Для цього плоди вишні сортів Шпанка та Лотівка 20162017 років врожаю обприскували за день до збирання водним розчином 50 мг/л чи 100 мг/л саліцилової кислоти (по чотири дерева кожного варіанту). Висушували природним шляхом. Через 24 години плоди, типові за забарвленням та формою, знімали 3 дерев і укладали в ящики №5 по 5 кг у кожний, згідно 3 методичними вказівками щодо зберігання плодів, овочів та винограду [1]. Зберігали в умовах холодильних камер кафедри технології зберігання і переробки плодів та овочів за температури $5 \pm 0,5^{\circ} \mathrm{C}$ та відносної вологості повітря 95 $\pm 1 \%$ за наступними варіантами: контроль - необроблені плоди та плоди вишні, оброблені розчином 50 мг/л чи 100 мг/л саліцилової кислоти.

Після зберігання проводили облік природних втрат маси шляхом зважування. Критерії закінчення зберігання плодів - втрати маси не більше $6 \%$ (Найченко, 2001) [3]. Визначення вмісту сухих розчинних речовин проводили на рефрактометрі РПЛ-3М, титрованих кислот - титрометричним методом [3], вмісту аскорбінової кислоти - йодометричним методом [3]. Математичну обробку даних проводили за Мойсейченко В.Ф. (1992) [2] на персональному комп'ютері за програмою «Excel 2000». 


\section{СІЛЬСЬКЕ ГОСПОДАРСТВО. РОСЛИННИЦТВО}

Результати досліджень. За результатами досліджень (рис. 1), обробка плодів вишні розчином саліцилової кислоти дала змогу подовжити тривалість зберігання до 21 доби. Втрати маси плодів вишні сортів Шпанка та Лотівка після 15денного зберігання становили $4,9 \%$ та $5,1 \%$. Для плодів вишні, оброблених $50 \mathrm{мг/л} \mathrm{та}$ $100 \mathrm{мг/л} \mathrm{розчином} \mathrm{саліцилової} \mathrm{кислоти,} \mathrm{вони}$ були меншими $-4,1-4,4 \%$ та 3,3-3,5 \%. Наймені втрати маси характерні для плодів вишні, оброблених розчином 100 мг/л саліцилової кислоти $(3,3 \%)$.

Вміст сухих розчинних речовин (рис. 2) для плодів вишні сортів Шпанка та Лотівка зменшився на $11 \%$ та 7,9\%. Втрати вмісту сухих розчинних речовин для плодів вишні сортів Шпанка та Лотівка, попередньо оброблених 50 мг/л та 100 мг/л розчином саліцилової кислоти, були меншими і становили 6,5-7,2 \% та 5,3-6,6 \% відповідно.

Одним із показників якості плодів вишні протягом зберігання $\epsilon$ вміст титрованих кислот. Їх кількість протягом усього періоду зберігання змінювалась (рис. 3). Для плодів вишні сортів Шпанка та Лотівка в контрольному варіанті він зменшився на $23 \%$ та $18 \%$. У плодах вишні, оброблених розчинами 50 мг/л та 100 мг/л, втрати вмісту титрованих кислот становили 30-16,3 \% та 12,3-9 \%. У випадку збільшення тривалості зберігання до 21 доби втрати титрованих кислот у плодах вишні були найменшими за обробки 100 мг/л розчином саліцилової кислоти (1 \%).

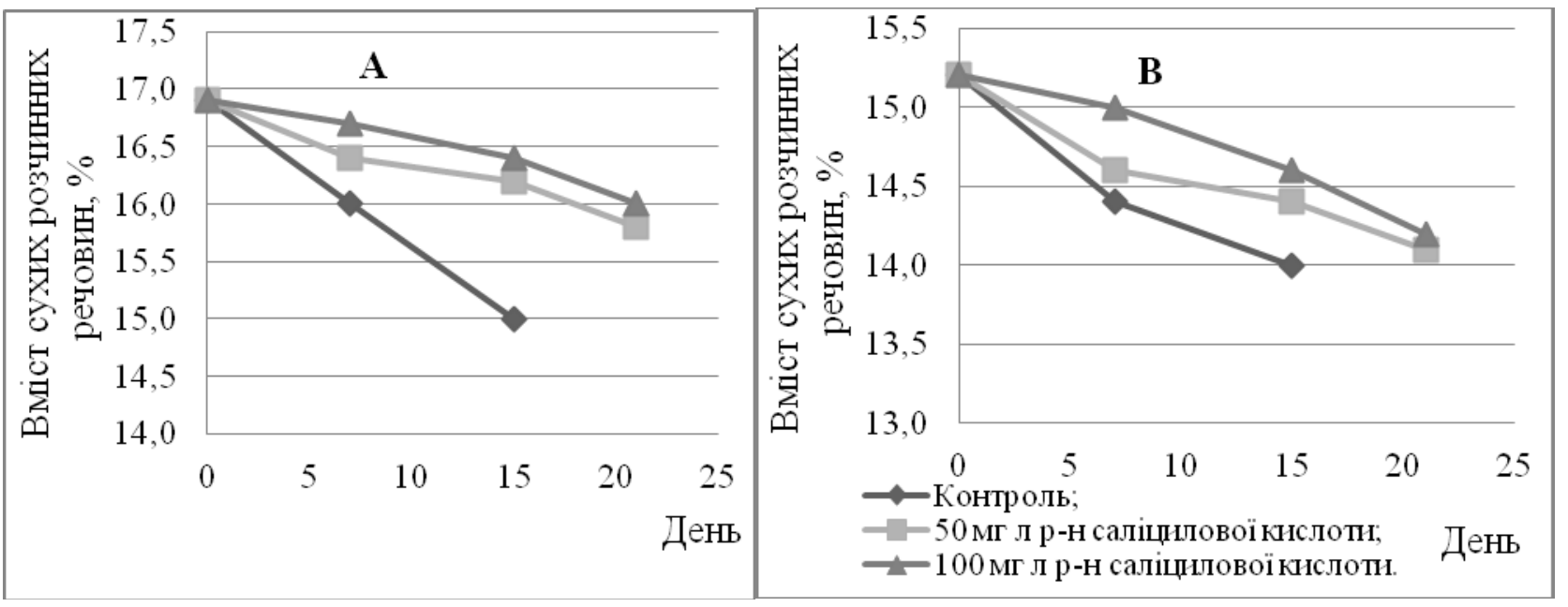

1. Динаміка вмісту сухих розчинних речовин у плодах вишні сорту (А) Шпанка та (В) Лотовка $\left(\right.$ HІР $\left._{05}=0,4\right)$, оброблених розчином саліцилової кислоти перед зберіганням

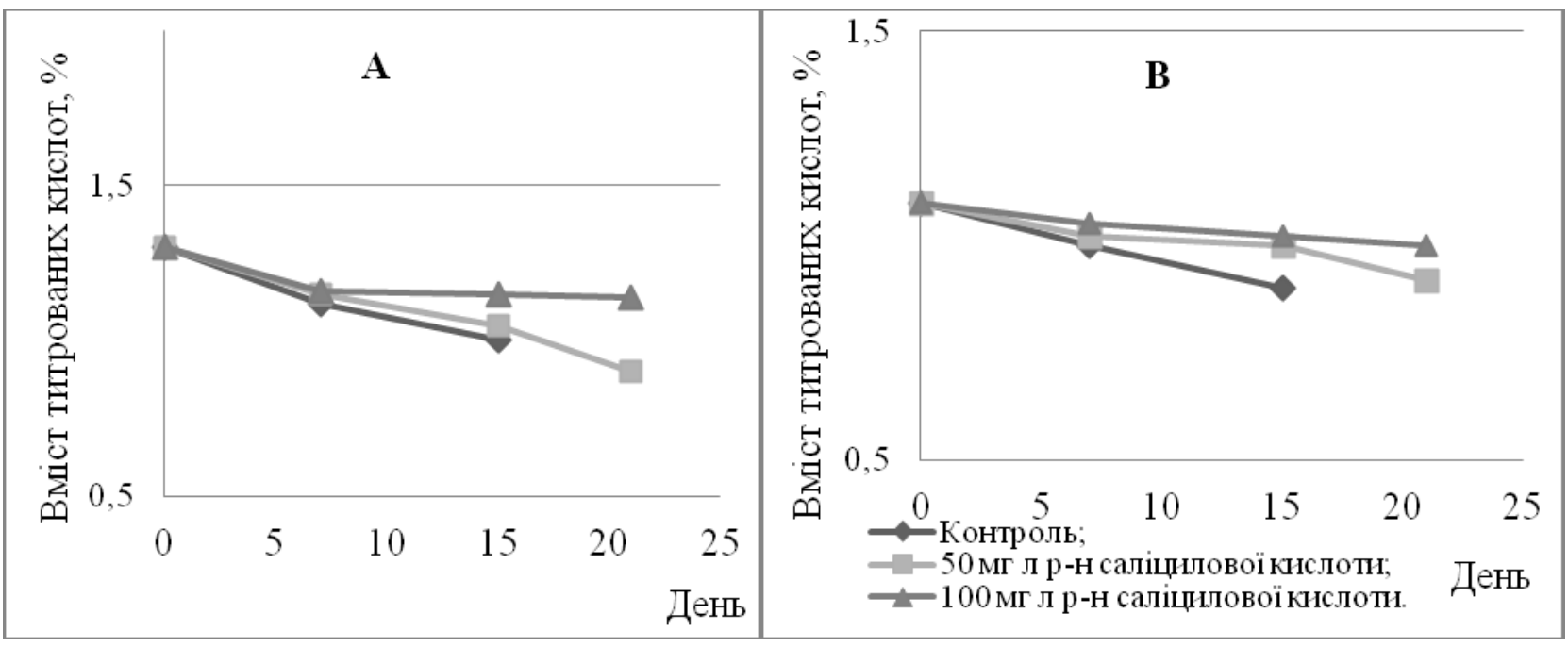

2. Динаміка вмісту титрованих кислот у плодах вишні сорту (А) Шпанка та (В) Лотівка $\left(\right.$ HIP $\left._{05}=0,4\right)$, оброблених розчином саліцилової кислоти перед зберіганням 
СІЛЬСЬКЕ ГОСПОДАРСТВО. РОСЛИННИЦТВО

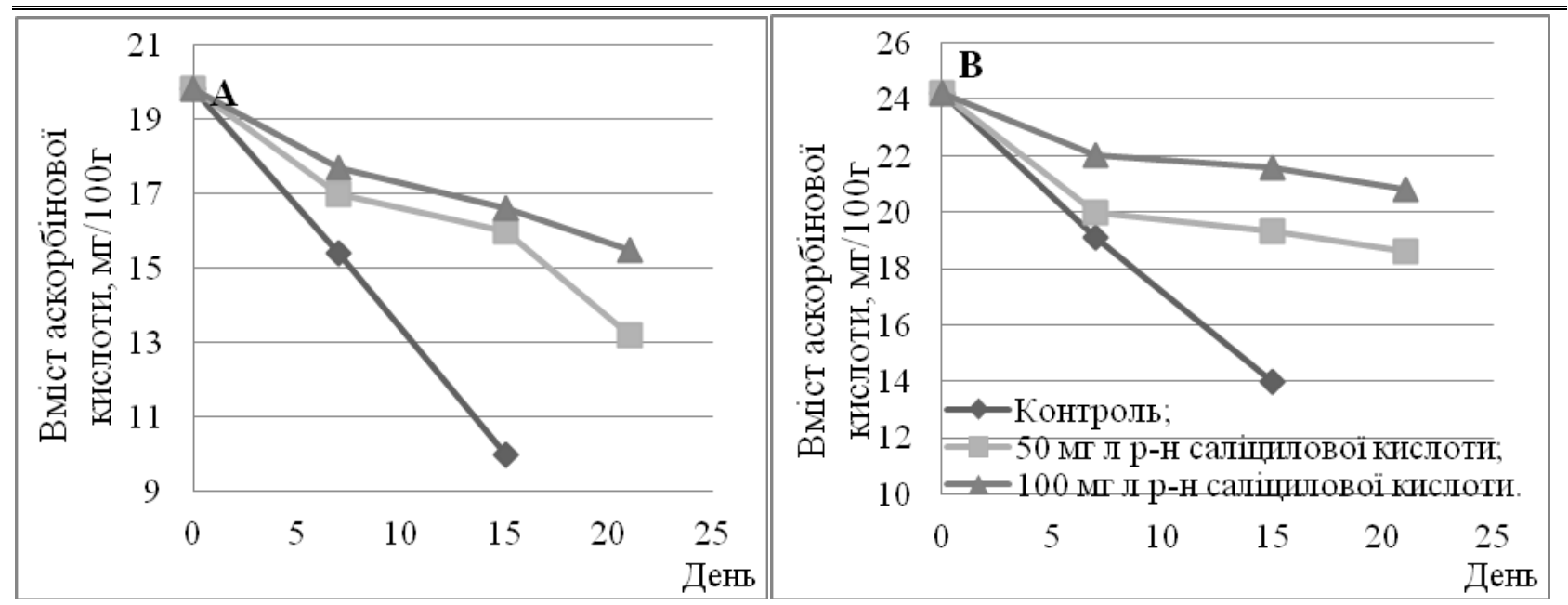

3. Динаміка вмісту аскорбінової кислоти в плодах виині сорту (А) Шианка та (В) Лотівка $\left(\right.$ HIP $\left._{05}=0,4\right)$, оброблених розчином саліцилової кислоти перед зберіганням

Під час зберігання плодів, зокрема вишні, в процесах дихання та транспірації беруть участь сухі розчинні речовини, кислоти, вітаміни. Протягом зберігання плодів вишні сортів Шпанка та Лотівка вміст аскорбінової кислоти знизився вдвічі. Зниження вмісту аскорбінової кислоти для плодів вишні сортів Шпанка і Лотівка, оброблених 50 мг/л розчином саліцилової кислоти, менше - в 1,5 і 1,3 раз та в $1,1-1,3$ рази для плодів вишні, оброблених 100 мг/л розчином саліцилової кислоти.

Для встановлення впливу особливостей сорту та виду обробки протягом зберігання (рис. 4) на рівень природних втрат маси був проведений дисперсійний аналіз, за результатами якого найбільше на втрати маси впливав вид обробки (фа- ктор В) з часткою участі $85,6 \%$. Тоді як частка участі інших факторів є дещо меншою: сорт (фактор А) - 2,2 \%, взаємодії факторів - 11,1\%.

Як показали результати кореляційного аналізу, рівень природних втрат маси обернено корелює з вмістом аскорбінової кислоти $(\mathrm{r}=-0,65)$ та титрованими кислотами $(\mathrm{r}=-0,57)$.

Висновок. Обробка плодів вишні розчином саліцилової кислоти подовжує термін зберігання до 21 доби. Найефективнішою виявилась обробка 100 мг/л розчином саліцилової кислоти. Природні втрати маси при цьому становлять 4,9$5,1 \%$, втрати у вмісті сухих розчинних речовин - 5,3-6,6 \%, кислот - 12,3-9 \%, аскорбінової кислоти - в 1,3-1,1 рази. На втрати маси найбільший вплив має фактор «вид обробки» $(85,6 \%)$.

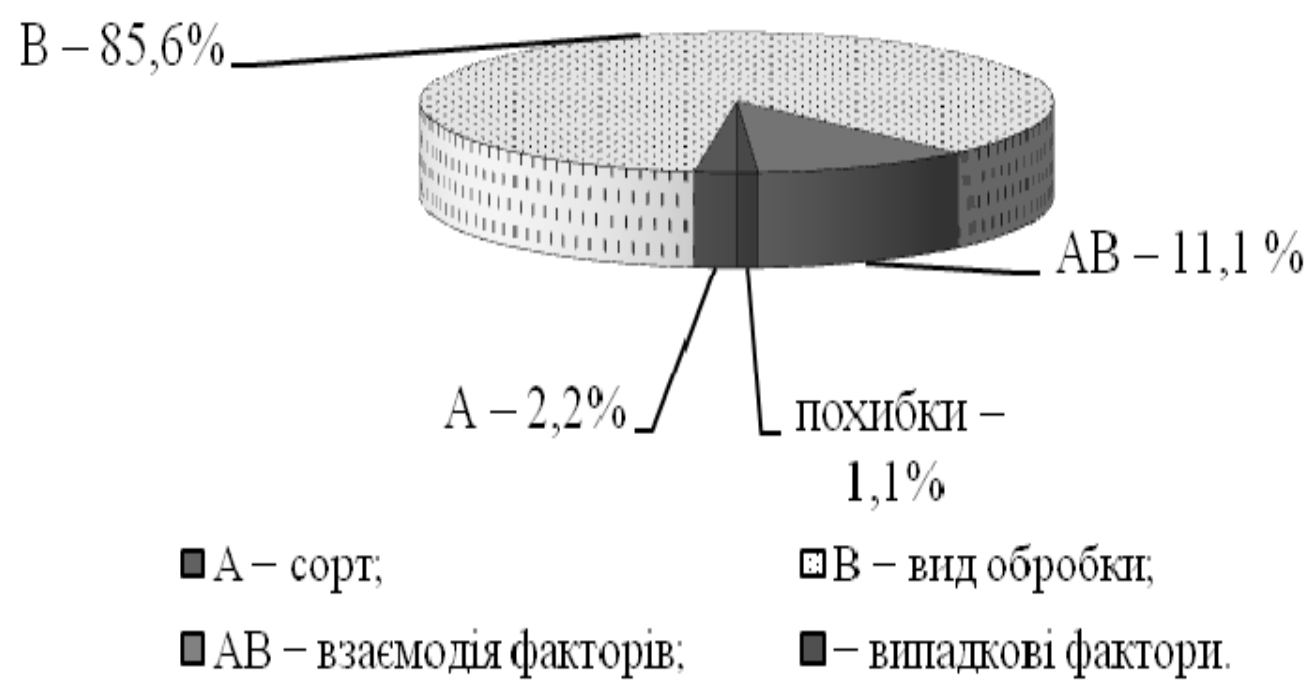

4. Частка впливу фактора А (сорт), В (вид обробки) на природні втрати маси плодів вищні 


\section{БІБЛІОГРАФІЯ}

1. Методические рекомендации по хранению плодов, овощей и винограда. Организация и проведения исследований. Под общей ред. С. Ю. Дженеева, В. И. Иванченко. - Ялта : Институт винограда и вина «Магарач», 1998. - 152 с.

2. Мойсейченко В. Ф. Основи наукових досліджень у плодівництві, овочівництві, виноградарстві та технології зберігання плодоовочевої продукції. - К. : НМК ВО, 1992. - 362 с.

3. Найченко В. М. Практикум з технології зберігання і переробки плодів та овочів з основами товарознавства: навчальний посібник. - К. : ФАДА ЛТД, 2001. - $211 \mathrm{c}$.

4. Gimenez M. J., Valverde J.M., Valero D., Guillen F., Martinez-Romero D., Serrano M., Castillo S. Quality and antioxidant properties on sweet cherries as affected by preharvest salicylic and acetylsalicylic acids treatments. Food Chemistry. - 2014. - Vol. 160. - P. 226-232.

5. Giménez M.J., Valverde J.M., Valero D., Zapata P.J., Castillo S., Serrano M. Postharvest methyl salicylate treatments delay ripening and maintain quality attributes and antioxidant compounds of 'Early Lory' sweet cherry. Postharvest Biology and Technology. - 2016. Vol. 117. - P. 102-109.

6. Kumar N., Tokas J., Kumar P., Singal H.R. Effect of salicylic acid on post-harvest quality of tomato (Solanum lycopersicum L.) fruit. International Journal of Chemical Studies. - 2018. - Vol. 6(1). - P. 1744-1747.

7. Martínez-Espla A., Serrano M., Valero D., Martínez-Romero D., $\quad$ Castillo S., Z Zapata P.J.

\section{ANNOTATION}

Vasylyshyna O.V. Effect of treatment with salicylic acid solution on the quality of cherry fruit after storage.

Cherry is fruit with a short shelf life of only 15 days at the temperature of $0{ }^{\circ} \mathrm{C}$. Every year about $20 \%$ of product losses are due to the lack of appropriate measures for primary processing and storage of products. Salicylic acid plays an important role in a wide range of physiological and metabolic reactions, including delayed maturation, by delaying the synthesis of ethylene and reducing the physiological diseases of the fruit. However, the effect of treatment with salicylic acid on cherry fruits and their physiological and biochemical parameters has not been investigated. Therefore, the purpose of our work was to study the effect of pretreatment with salicylic acid solution on the chemical composition of cherry fruit.
Enhancement of antioxidant systems and storability of two plum cultivars by preharvest treatments with salicylates. International Journal of Molecular Sciences. - 2017. - Vol. 18 (9). - P. 1911.

8. Soleimani Aghadam M., Asghari M. R., Moradbeygi H., Mohammadkhani N., Mohayeji M., Rezapour-Fard $J$. Effect of postharvest salicylic acid treatment on reducing chilling injury in tomato fruit. Romanian Biotechnological Letters, 2012. Vol. 17 (2). - P. 7466-7473.

9. Valero D., Díaz-Mula H.M., Zapata P. J., Castillo S., Guillén F., Martínez R.D., Serrano M. Postharvest treatments with salicylic acid, acetylsalicylic acid or oxalic acid delayed ripening and enhanced bioactive compounds and antioxidant capacity in sweet cherry. Journal of Agricultural and Food Chemistry. - 2011. - Vol. 59 (10). - P. 5483-5489.

10. Vasylyshyna $O$. Changes in antioxidant activity of cherry fruits and grapes during freezing. Journal of Food, Agriculture \& Environment. 2017. - №15 (2). - P. 61-63.

11. Wani A. A., Singh P., Gul K., Wani M. H., Langowski H. C. Sweet cherry (Prunus avium): Critical factors affecting the composition and shelf life. Food Packaging and Shelf Life. - 2014. - Vol. 1(1). - P. 86-99.

12. Wang Z., Ma L., Zhang X., Xu L., Cao J., Jiang $W$. The effect of exogenous salicylic acid on antioxidant activity, bioactive compounds and antioxidant system in apricot fruit. Scientia Horticulturae. - 2015. - Vol. 181(2). - P. 113-120.

For this purpose, the day before harvesting with the cherry varieties of Shpanka and Lotivka of the yield of the year 2016-2017 were sprayed the aqueous solution of $50 \mathrm{mg} / \mathrm{l}$ or $100 \mathrm{mg} / \mathrm{l}$ of salicylic acid. They were dried by natural way. After 24 hours, the fruit of typical colour and shape were taken from the tree, placed in boxes of 5 to $5 \mathrm{~kg}$ each, according to the guidelines for the storage of fruit, vegetables, and grapes. We preserved them in the conditions of the refrigerating chambers of the department of the technology of storage and processing of fruit and vegetables at the temperature of $5 \pm 0,5^{\circ} \mathrm{C}$ and relative humidity of $95 \pm 1 \%$. The options were the following: control - unprocessed fruit and cherry fruit treated with a solution of $50 \mathrm{mg} / \mathrm{l}$ or $100 \mathrm{mg} / \mathrm{l}$ of salicylic acid.

The processing of cherry fruit with a solution of salicylic acid allowed to extend the shelf life to 21 
days. The most effective treatment was $100 \mathrm{mg} / \mathrm{l}$ solution of salicylic acid. Natural mass losses in this case are $4.9-5.1 \%$, losses in the content of dry soluble substances $5.3-6.6 \%$, acids $12.3-9 \%$, the losses of ascorbic acid are reduced in 1.3-1.1 times.

As the results of the correlation analysis showed, the level of natural mass losses strongly is correlated with the content of ascorbic acid $(\mathrm{r}=-0.65)$ and titrated acids $(r=-0.57)$. The weight loss factor has the greatest influence on the type of treatment $(85.6 \%)$.

Key words: cherry fruit, storage, salicylic acid, dry soluble substances, ascorbic acid. 